\title{
Metabolism of Human Serum Albumin in Man during Acute Exposure to High Altitude (14,100 Feet)*
}

\author{
Martin I. Surks $\dagger$ \\ (From the Physiology Division, U.S. Army Medical Research and Nutrition Laboratory, \\ Fitzsimons General Hospital, Denver, Colo.)
}

The effect of high altitude exposure on protein metabolism in man has not been fully investigated. In a recent study of eight sea level residents (1), the concentration of plasma total protein and of the specific proteins thyroxine-binding globulin and ceruloplasmin was noted to be increased during the first 2 weeks of exposure to high altitude. Since the electrophoretic distribution of the plasma proteins was unchanged, the observations were interpreted as resulting from marked water loss from the intravascular compartment. In contrast to these changes, the concentration of thyroxinebinding prealbumin (TBPA) was decreased during this period. Alterations in the metabolism of this plasma protein may be manifest rapidly by changes in its concentration due to its rapid rate of metabolism $(2,3)$. Thus, the reduced concentration of TBPA noted at high altitude was interpreted to reflect possible changes in plasma protein synthesis or degradation in this environment that had been masked by the dehydration of the intravascular compartment.

In the present investigation, the turnover of ${ }^{131}$ I-labeled albumin was studied in five subjects during a control period at 5,280 feet and for eight days at 14,100 feet. The method of data analysis allowed an independent estimate of the daily rate of albumin synthesis and degradation during the experimental period. These observations were correlated with simultaneous measurements of gross nitrogen balance, TBPA concentration, and various indexes of thyroid function.

* Submitted for publication March 3, 1966; accepted June 8, 1966.

Portions of this work have appeared in Fed. Proc. 1966, 25, 399.

$\dagger$ Address requests for reprints to Dr. Martin I. Surks, 1749 Grand Concourse, Bronx, N. Y. 10453.

\section{Methods}

Human serum albumin ${ }^{-131}{ }^{-}$was obtained commercially 1 and initially contained less than $1 \mathrm{~g}$-atom iodine per g-molecule albumin. It was shipped as a $1 \%$ solution (97.2 $\mu \mathrm{c}$ per $\mathrm{ml}$ ) and was further diluted with $1 \%$ human serum albumin immediately after receipt in the laboratory. The preparation contained $4.2 \%$ inorganic iodide $-{ }^{131} \mathrm{I}$ as determined by rapid paper electrophoresis (4). After addition to human serum, $1 \mu \mathrm{c}$ per $\mathrm{ml}$, vertical starch gel electrophoresis was performed for 16 hours in a borate buffer at a potential difference of $125 \mathrm{v}$. More than $95 \%$ of the radioactivity in the starch gel migrated with the albumin band (Figure 1). Sterilization was achieved by two passages through a $0.22-\mu$ Millipore filter. The sterilized material was stored at $3^{\circ} \mathrm{C}(72$ hours) and had a concentration of $4.6 \mu \mathrm{c}$ per $\mathrm{ml}$ on the day of injection.

Five soldiers, aged 19 to 23 years, were used as volunteer subjects. They were in good health and had been residents of Denver, Colorado, for at least 3 months before the onset of the study. During the control period, carried out at 5,280 feet altitude, they remained in a metabolic ward where they were offered a diet that supplied $3,000 \mathrm{kcal}$ per day containing 1.1 to $1.5 \mathrm{~g}$ protein per $\mathrm{kg}$ body weight per day. Lugol's solution, 20 drops per day, was administered on the day preceding the injection of albumin- ${ }^{131} \mathrm{I}$ and daily throughout the study to limit thyroidal uptake of iodide- ${ }^{131} \mathrm{I}$ released from degraded protein. On the first experimental day, 16 to $18 \mu \mathrm{c}$ albumin- ${ }^{-131} \mathrm{I}$ (35 to $39 \mathrm{mg}$ albumin) was injected from weighed syringes into the tubing of a running intravenous infusion of $5 \%$ dextrose in water. Subsequent counting demonstrated less than $0.005 \%$ of the injected dose remaining in the intravenous tubing. Fifteen $\mathrm{ml}$ heparinized blood was withdrawn without stasis $10 \mathrm{~min}$ utes after the injection of the albumin $-{ }^{131} I$ and daily thereafter. All urine and stool was collected and kept at $5^{\circ} \mathrm{C}$. Plasma and samples from 24-hour urine pools and from homogenates of 4-day stool collections (delimited by carmine markers) were stored frozen at $-20^{\circ}$ $C$ until needed for radioactive or chemical assay.

After 10 days at 5,280 feet, the subjects were rapidly transported ( $2 \frac{1}{2}$ hours) to the summit of Pikes Peak, Colorado $(14,100$ feet altitude). There they were housed in a laboratory trailer in which the temperature was maintained at $18^{\circ}$ to $21^{\circ} \mathrm{C}$. The environmental tem-

1 Abbott Laboratories, North Chicago, Ill. 
perature varied between $-10^{\circ}$ and $+14^{\circ} \mathrm{C}$ and the relative humidity between 15 and $25 \%$. The diet and collections of blood, urine, and stool were continued unchanged. Efforts were made to maintain a degree of physical activity similar to that at the lower altitude. The subjects remained at high altitude for 8 days and then returned to 5,280 feet for a 4-day postaltitude period.

Samples of plasma, urine, and stool were counted with appropriate standards in a Packard Auto-gamma spectrometer, series $314 \mathrm{E}$, with a counting error of less than 1\%. Plasma volume was calculated on the basis of the concentration of radioactivity in the plasma obtained 10 minutes after injection of the albumin- ${ }^{201} \mathrm{I}$. Three subsequent measurements of plasma volume were made photometrically with Evans blue dye (T-1824), one on the sixth day of the control period and one each on the fourth and eighth days of altitude exposure. The subjects were fasting and were required to remain supine for at least 1 hour before each of these determinations. Plasma albumin concentration was calculated as the product of the plasma total protein concentration (5) and the percentage of albumin on stained plasma electrophoretograms. ${ }^{2}$ By this technique the mean \pm standard deviation of eight measurements of the same normal plasma performed on different days was $4.40 \pm 0.15 \mathrm{~g}$ per $100 \mathrm{ml}$. Nitrogen was measured in urine, stool, and homogenates of 2-day diet composites by the Kjeldahl technique (6). The completeness of urine collections was checked by creatinine excretion. In some of the plasma samples, total thyroxine concentration (7),,$^{8}$ free thyroxine concentration ( 8 ), and the maximal binding capacity of thyroxine-binding prealbumin (8) were also determined.

Data analysis. The data were analyzed on the basis of an open two-compartment mamillary model by the graphic method of Pearson, Veall, and Vetter (9), which is based on the observations of Berson, Yalow, Schreiber, and Post (10) and Campbell, Cuthbertson, Matthews, and McFarlane (11). After radioactive assay the following functions were calculated daily and plotted on semilogarithmic paper: $Q_{\mathbf{P}}$, the per cent of the injected dose in the plasma (per cent of dose per milliliter plasma multiplied by the plasma volume); $Q_{R}$, the per cent of the injected dose remaining in the body (injected dose minus the cumulative losses due to the excretion of urine and stool and withdrawal of blood); and $Q \mathbf{w}$, the per cent of the injected dose in the extravascular compartment $\left(Q_{R}\right.$ minus $\left.Q_{P}\right)$. The fractional rate of degradation of plasma albumin $\left(k_{d}\right)$ was determined by dividing the per cent of the dose excreted in the urine by the average $Q_{P}$ of the same day. The albumin degradation rate was obtained by the product of $k_{a}$ and the plasma albumin pool. A line with a slope corresponding to $\mathbf{k}_{\mathbb{d}}$ was then constructed tangent to the $Q_{P}$ curve. The point of contact defined that point in time $\left(T_{\mathbb{w}}\right)$ when the spe-

\footnotetext{
2 Beckman (South Pasadena, Calif.) electrophoresis membranes, no. 324330 .

${ }^{8}$ Bio-Science Laboratories, Los Angeles, Calif.
}

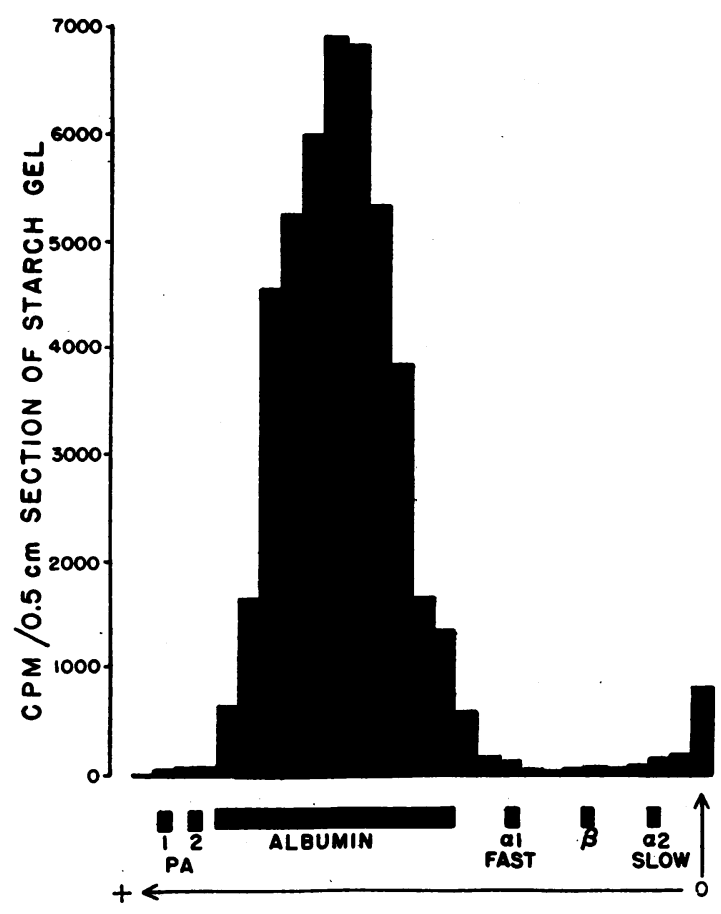

Fig. 1. Distribution OF ALBUMIN- ${ }^{201}$ I AMONG THE PLASMA PROTEINS SEPARATED BY STARCH GEL ELECTROPHORESIS. The stain of representative proteins is also shown. $\mathrm{O}=$ origin, $t=$ anode, $\mathrm{PA}=$ prealbumin.

cific activity of albumin was presumed identical in the intravascular (IV) and extravascular (EV) compartments. The magnitude of the total exchangeable albumin pool could then be calculated on the basis of the plasma specific activity and $Q_{P}$ and $Q_{\mathbf{V}}$ at $T_{\mathbf{H}}$.

Albumin synthesis was equated to degradation only during the control period. However, analysis of the extravascular to intravascular distribution ratio $\left(Q_{m} / Q_{P}\right)$ and the rates of change of the $Q$ and plasma albumin specific activity curves by the method of Matthews (12) resulted in an estimate of albumin synthesis + net transfer from the EV to IV compartment $\left(k_{1 n}\right)$ (per cent of the IV pool replaced per day) that was independent of changes in pool size and transfer rates. This method involves no assumptions other than those inherent in the method of data analysis described above (9). During the control period the rates of change of these curves were obtained by their slopes. At high altitude, however, the curves were often complex and it was necessary to derive polynomial exponential expressions to adequately describe them. This was accomplished by stepwise regression in an IBM 1044 digital computer (13). The first derivative of the derived polynomial gave the instantaneous rate of change at any point in time. Estimates based on the precision of the plasma albumin determinations and radioactive measurements indicate that the calculated $\mathbf{k}_{\text {in }}$ may vary by as much as 20 to $30 \%$. Thus, only large changes in this function 
TABLE I

Turnover of albumin-131 I during the control period*

\begin{tabular}{|c|c|c|c|c|c|c|c|c|c|c|}
\hline \multirow[b]{2}{*}{ Subject } & \multirow[b]{2}{*}{ Height } & \multirow{2}{*}{$\begin{array}{l}\text { Initial } \\
\text { weight }\end{array}$} & \multirow{2}{*}{$\begin{array}{l}\text { IV albu- } \\
\text { min pool }\end{array}$} & \multicolumn{3}{|c|}{ Albumin degradation rate } & \multirow{2}{*}{$\begin{array}{l}\mathrm{EV} / \mathrm{IV} \\
\text { distri- } \\
\text { bution }\end{array}$} & \multirow{2}{*}{\multicolumn{2}{|c|}{$\begin{array}{l}\text { Total exchangeable } \\
\text { albumin pool }\end{array}$}} & \multirow{2}{*}{$\underset{t}{\text { Biological }}$} \\
\hline & & & & Fractional & $\mathrm{Ab}$ & & & & & \\
\hline & $\mathrm{cm}$ & $k g$ & $g$ & $d a y^{-1}$ & \multicolumn{2}{|c|}{ g/day $\mathrm{g} / \mathrm{kg} /$ day } & & $g$ & $\mathrm{~g} / \mathrm{kg}$ & days \\
\hline J.G. & 173 & 61.28 & 124.3 & 0.1164 & 14.47 & 0.236 & 1.40 & 276.4 & 4.51 & 13.24 \\
\hline J.S. & 186 & 75.60 & 171.3 & 0.1094 & 18.74 & 0.248 & 1.34 & 383.2 & 5.07 & 15.11 \\
\hline D.T. & 173 & 65.19 & 133.3 & 0.1273 & 16.97 & 0.260 & 1.45 & 283.1 & 4.34 & 11.56 \\
\hline L.W. & 162 & 67.73 & 119.7 & 0.1231 & 14.74 & 0.218 & 1.31 & 240.0 & 3.54 & 11.28 \\
\hline D.D. & 185 & 83.16 & 134.2 & 0.1151 & 15.42 & 0.185 & 1.55 & 300.8 & 3.62 & 13.52 \\
\hline Mean & 176 & 70.59 & 136.6 & 0.1183 & 16.07 & 0.229 & 1.41 & 296.7 & 4.22 & 12.94 \\
\hline
\end{tabular}

* Abbreviations: IV = intravascular $; \mathrm{EV}=$ extravascular.

should be considered important. Data were expressed as the arithmetic mean \pm standard error, according to the methods of Johnson (14).

\section{Results}

General. The nature of the radioactivity in the plasma and urine was determined in each subject during the control period and at high altitude. Equal volumes of cold $15 \%$ trichloroacetic acid (TCA) were added to samples of urine, and plasma and the precipitates formed were washed twice with cold $1 \%$ TCA. Radioactive assay of the precipitates and the supernatant solutions revealed that more than $99 \%$ of the radioactivity in the plasma and less than $1 \%$ of the radioactivity in the urine were protein bound. The effectiveness of thyroidal blockade by stable iodide administration was measured by counting over the thyroid gland preceding and succeeding altitude ex-

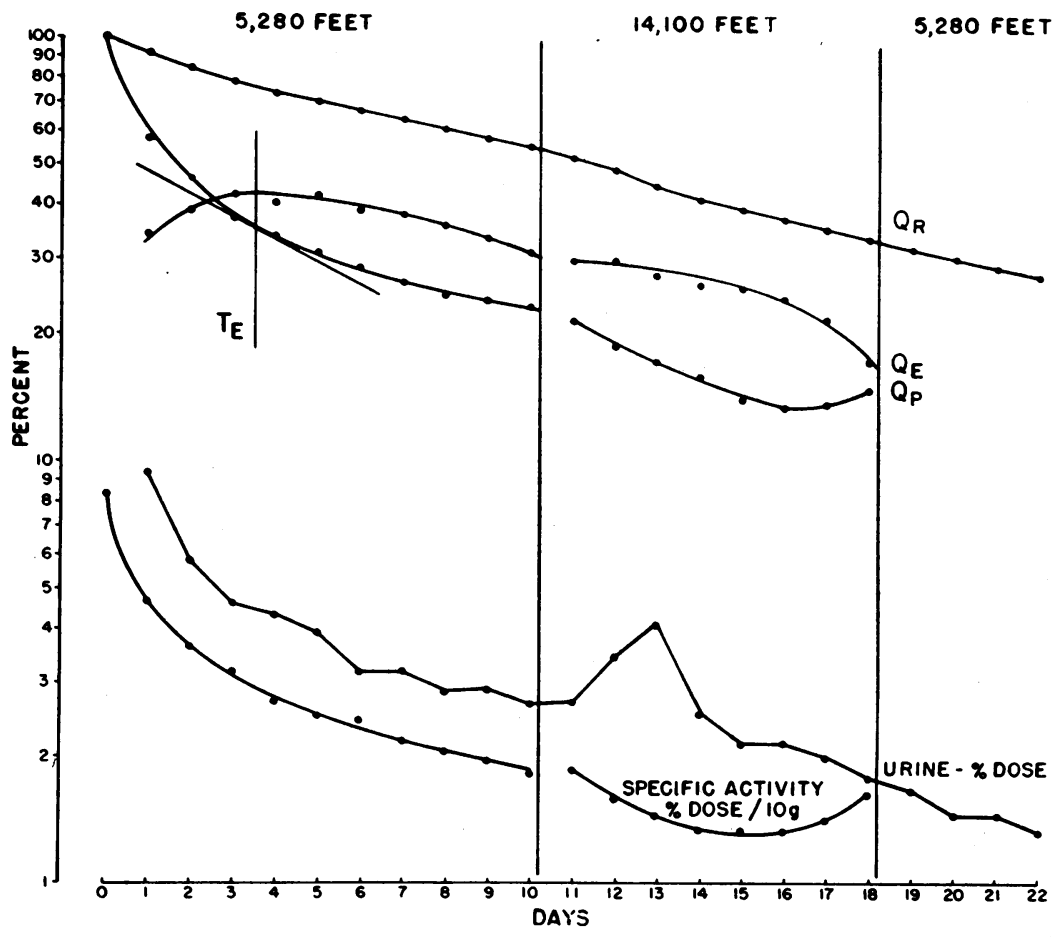

Fig. 2. Albumin- ${ }^{-181} I$ turnover data in subject J.G. $Q_{R}$ is the per cent of the injected dose remaining in the body; $Q_{m}$ and $Q_{P}$ are the per cent of the injected dose in the extravascular and intravascular compartments, respectively. $T_{\mathrm{m}}$ represents the equilibrium time, i.e., when the specific activity is equal in both compartments. 
posure. All counts revealed less than $1.5 \%$ of the injected dose had been accumulated by the thyroid.

Albumin turnover. The size of the intravascular and total exchangeable albumin pools and the albumin degradation rates during the control period are presented in Table I. The data from a representative subject are plotted in Figure 2. The mean fractional rate of degradation in the control period was $0.1183 \pm 0.0031$ (SEM) per day, which resulted in the degradation of $16.07 \pm 0.80$ $\mathrm{g}$ albumin per day. Calculations based on the total albumin pool and the degradation rate showed that the biological half-time of the preparation of labeled albumin employed varied between 11.28 and 15.11 days. ${ }^{4}$

Plasma volume, the only pool directly measured, was constant in the control period but significantly

TABLE II

Plasma volume, albumin concentration, and total plasma albumin during the control period and at 14,100 feet altitude

\begin{tabular}{|c|c|c|c|}
\hline \multirow[b]{2}{*}{ Subjects } & \multirow[b]{2}{*}{ Control } & \multicolumn{2}{|c|}{ Days at 14,100 feet } \\
\hline & & 4 & 8 \\
\hline & \multicolumn{3}{|c|}{ Plasma volume $(L)$} \\
\hline $\begin{array}{l}\text { J.G. } \\
\text { J.S. } \\
\text { D.T. } \\
\text { L.W. } \\
\text { D.D. }\end{array}$ & $\begin{array}{l}2.725^{*} \\
3.782 \\
3.065 \\
2.541 \\
3.117\end{array}$ & $\begin{array}{l}2.140 \\
3.167 \\
2.766 \\
2.414 \\
2.842\end{array}$ & $\begin{array}{l}2.027 \\
2.911 \\
2.499 \\
2.150 \\
2.591\end{array}$ \\
\hline \multirow[t]{2}{*}{ Mean } & 3.046 & 2.666 & 2.436 \\
\hline & \multicolumn{3}{|c|}{$\begin{array}{l}\text { Plasma albumin concentration } \\
\qquad(\mathrm{g} / 100 \mathrm{ml})\end{array}$} \\
\hline $\begin{array}{l}\text { J.G. } \\
\text { J.S. } \\
\text { D.T. } \\
\text { L.W. } \\
\text { D.D. }\end{array}$ & $\begin{array}{l}4.56 \dagger \\
4.53 \\
4.35 \\
4.71 \\
4.31\end{array}$ & $\begin{array}{l}4.76 \\
4.79 \\
4.37 \\
4.16 \\
4.57\end{array}$ & $\begin{array}{l}4.57 \\
4.26 \\
3.95 \\
4.51 \\
4.63\end{array}$ \\
\hline \multirow[t]{2}{*}{ Mean } & 4.49 & 4.53 & 4.38 \\
\hline & \multicolumn{3}{|c|}{ Total plasma albumin $(g)$} \\
\hline $\begin{array}{l}\text { J.G. } \\
\text { J.S. } \\
\text { D.T. } \\
\text { L.W. } \\
\text { D.D. }\end{array}$ & $\begin{array}{l}124.3 \\
171.3 \\
133.3 \\
119.7 \\
134.2\end{array}$ & $\begin{array}{l}101.8 \\
151.7 \\
120.9 \\
100.4 \\
130.0\end{array}$ & $\begin{array}{r}92.6 \\
123.6 \\
98.7 \\
97.0 \\
120.0\end{array}$ \\
\hline Mean & 136.6 & 121.0 & 106.4 \\
\hline
\end{tabular}

* Average of two determinations.

† Average of eight determinations.

$4 t_{\frac{1}{3}}=[0.693$ (total albumin pool)]/amount albumin degraded per day. This represents an artificial half-time, since its calculation assumes a one-compartment model. It is presented to facilitate comparisons with other studies.

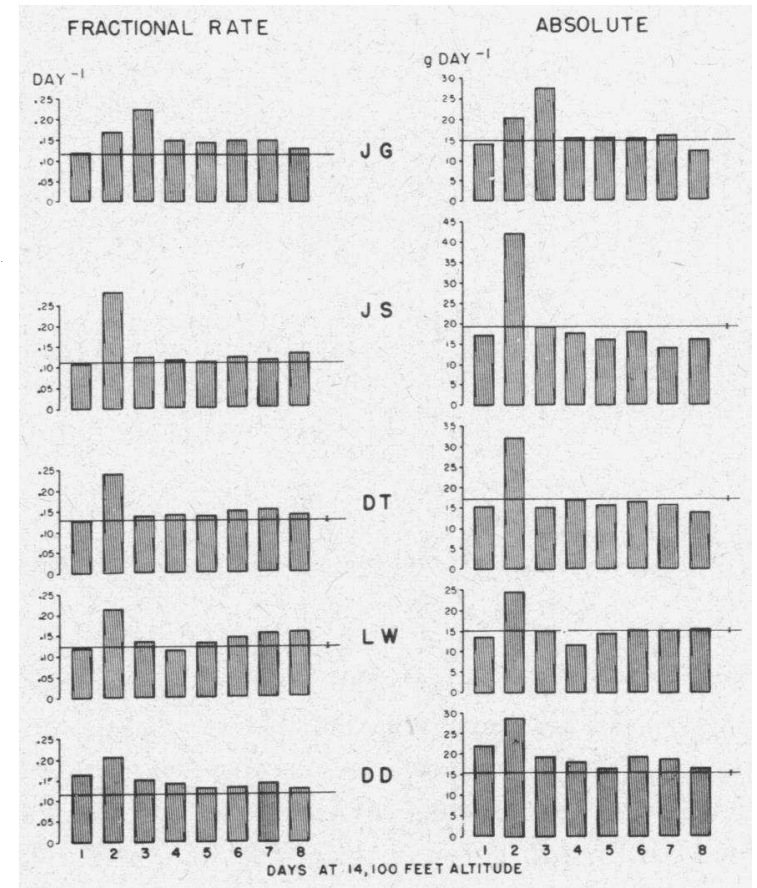

Fig. 3. Albumin Degradation in man at high ALTITUDE. The horizontal lines show the mean control degradation rates with the standard error shown on the right. Calculations of mean \pm standard error were based on data from 10 days in the control period. When no standard error of the mean is shown, it falls within the thickness of the horizontal line.

decreased in every subject at altitude (Table II). The mean reduction from the control volumes was $12.5 \%$ at 4 days and $20.0 \%$ at 8 days at 14,100 feet. Plasma volumes on the days between these determinations were calculated by interpolation. Plasma albumin concentration was stable during the control period but increased transiently in three of the five subjects at altitude. The increased albumin concentration appeared to be due entirely to an increase in total protein concentration, since the electrophoretic distribution of the plasma proteins was unchanged throughout the study. In this study any elevation in plasma albumin concentration was less than the decrease in plasma volume resulting in a decreasing plasma albumin pool in all subjects at altitude (Table II).

The fractional rate of degradation $\left(k_{d}\right)$ of albumin-131 I was increased in all subjects at 14,100 feet (Figure 3 ). The changes were most marked during the first 3 days, but the mean percentage increase in $\mathrm{k}_{\mathrm{d}}$ remained 11 to $18 \%$ higher than the control even during the last 5 days at altitude. 
TABLE III

The rate of albumin synthesis + net transfer from the extravascular to intravascular compartments during the control period and at high altitude*

\begin{tabular}{|c|c|c|c|c|c|c|c|c|c|c|}
\hline \multirow[b]{3}{*}{ Subject } & \multirow[b]{3}{*}{$\mathbf{k}_{\mathbf{d}}$} & \multirow{3}{*}{$\begin{array}{l}\text { Control } \\
\text { period }\end{array}$} & \multicolumn{7}{|c|}{$\mathrm{k}_{\mathrm{in}}$} & \multirow[b]{3}{*}{8} \\
\hline & & & \multicolumn{7}{|c|}{ Days at 14,100 feet altitude } & \\
\hline & & & 1 & 2 & 3 & 4 & 5 & 6 & 7 & \\
\hline $\begin{array}{l}\text { J.G. } \\
\text { J.S. } \\
\text { D.T. } \\
\text { L.W. } \\
\text { D.D. }\end{array}$ & $\begin{array}{l}11.64 \\
10.94 \\
12.73 \\
12.31 \\
11.51\end{array}$ & $\begin{array}{l}13.72 \\
10.55 \\
15.12 \\
13.86 \\
15.55\end{array}$ & $\begin{array}{l}12.37 \\
17.69 \\
20.24 \\
18.19 \\
17.66\end{array}$ & $\begin{array}{l}11.42 \\
18.32 \\
24.29 \\
20.24 \\
16.10\end{array}$ & $\begin{array}{l}14.74 \\
12.14 \\
12.73 \\
14.69 \\
14.23\end{array}$ & $\begin{array}{l}15.92 \\
11.33 \\
11.54 \\
11.43 \\
10.57\end{array}$ & $\begin{array}{r}18.25 \\
13.68 \\
10.81 \\
8.81 \\
12.13\end{array}$ & $\begin{array}{l}14.53 \\
13.37 \\
10.79 \\
10.70 \\
14.14\end{array}$ & $\begin{array}{r}5.60 \\
11.16 \\
5.97 \\
2.09 \\
14.83\end{array}$ & $\begin{array}{r}-5.17 \\
8.86 \\
4.72 \\
-5.52 \\
3.42\end{array}$ \\
\hline Mean & 11.83 & 13.76 & 17.23 & 18.07 & 13.71 & 12.16 & 12.74 & 12.71 & 7.93 & 1.26 \\
\hline
\end{tabular}
per day.

* Abbreviations $: k_{d}=$ albumin-181 I degradation rate during the control period; $k_{i n}=$ per cent of IV pool replaced

The absolute degradation of albumin (grams per day) was also elevated early during altitude exposure. Here, however, the changes were smaller in magnitude than those of $\mathbf{k}_{\mathbf{d}}$ due to the progressive diminution of the plasma albumin pool. In

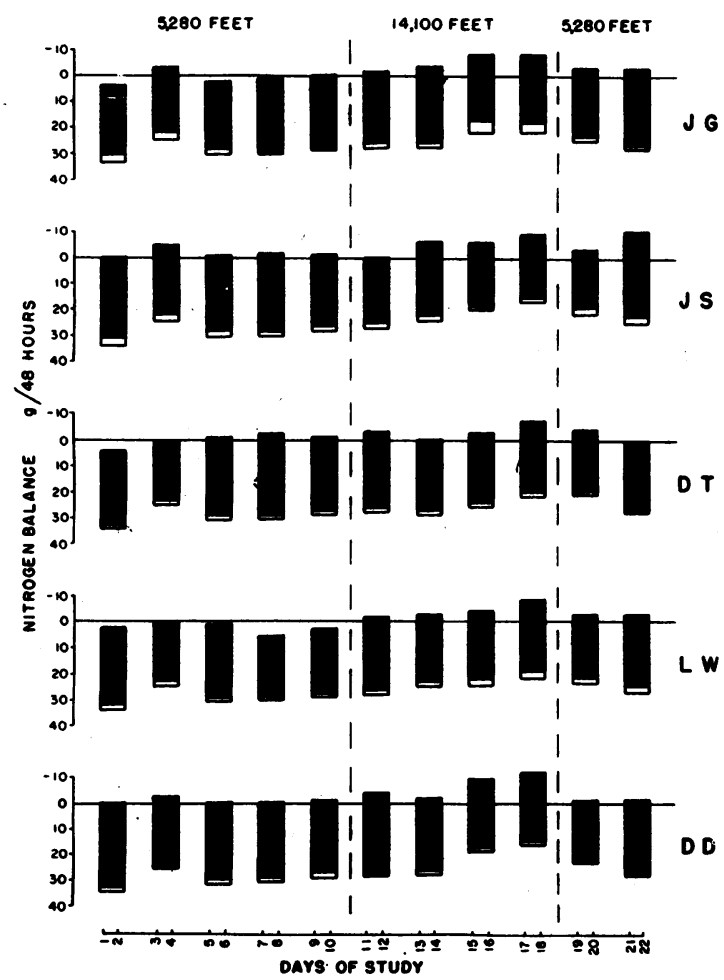

Fig. 4. Nitrogen balance in man at high altitude. Intake is plotted downward from the horizontal lines. The open areas represent stool nitrogen and the black areas nitrogen losses in the urine, sweat (estimated at $15 \mathrm{mg}$ per hour), and blood. the last days at altitude, albumin degradation was increased only in subject D.D.

If we assume that albumin synthesis was equal to degradation in the control period, the mean rate of synthesis was equivalent to $\mathbf{k}_{\mathbf{d}}$ ( $11.83 \%$ intravascular albumin pool per day) (Table III). This assumption was not made at altitude because of the lack of knowledge regarding possible changes in the total exchangeable albumin pool. Mean $\mathrm{k}_{\text {in }}$, calculated from the $Q_{\mathbb{E}}: Q_{P}$ ratio and the rates of change of the $Q_{\mathrm{E}}$ and plasma albumin specific activity curves, was $13.76 \%$ per day in the control period and was increased to 17.23 and $18.07 \%$ per day on the first 2 days at altitude. From the third through the sixth days mean $k_{\text {in }}$ was slightly lower than the control, and on days 7 and 8 it was reduced to 7.93 and $1.25 \%$ per day despite a marked shift of radioactivity from the EV to IV compartments (Figure 2). In J.G. and L.W. there was a calculated net loss of albumin from the plasma pool on the last altitude day.

Metabolic balance studies. The subjects accepted a diet that provided $3,000 \mathrm{kcal}$ per day during the control period, but they ingested less at altitude. The mean minimal caloric intake was $2,100 \mathrm{kcal}$ per day. The mean protein intake was $1.32 \mathrm{~g}$ per $\mathrm{kg}$ per day and fell progressively with the caloric intake to $0.90 \mathrm{~g}$ per $\mathrm{kg}$ per day during the last 2 days at altitude. Three of the five subjects were in nitrogen balance during the control period, L.W. being in slight positive balance (1.25 g per day) and J.S. in slight negative balance ( $-1.06 \mathrm{~g}$ per day) (Figure 4 ). Altitude exposure induced a mean negative nitrogen bal- 


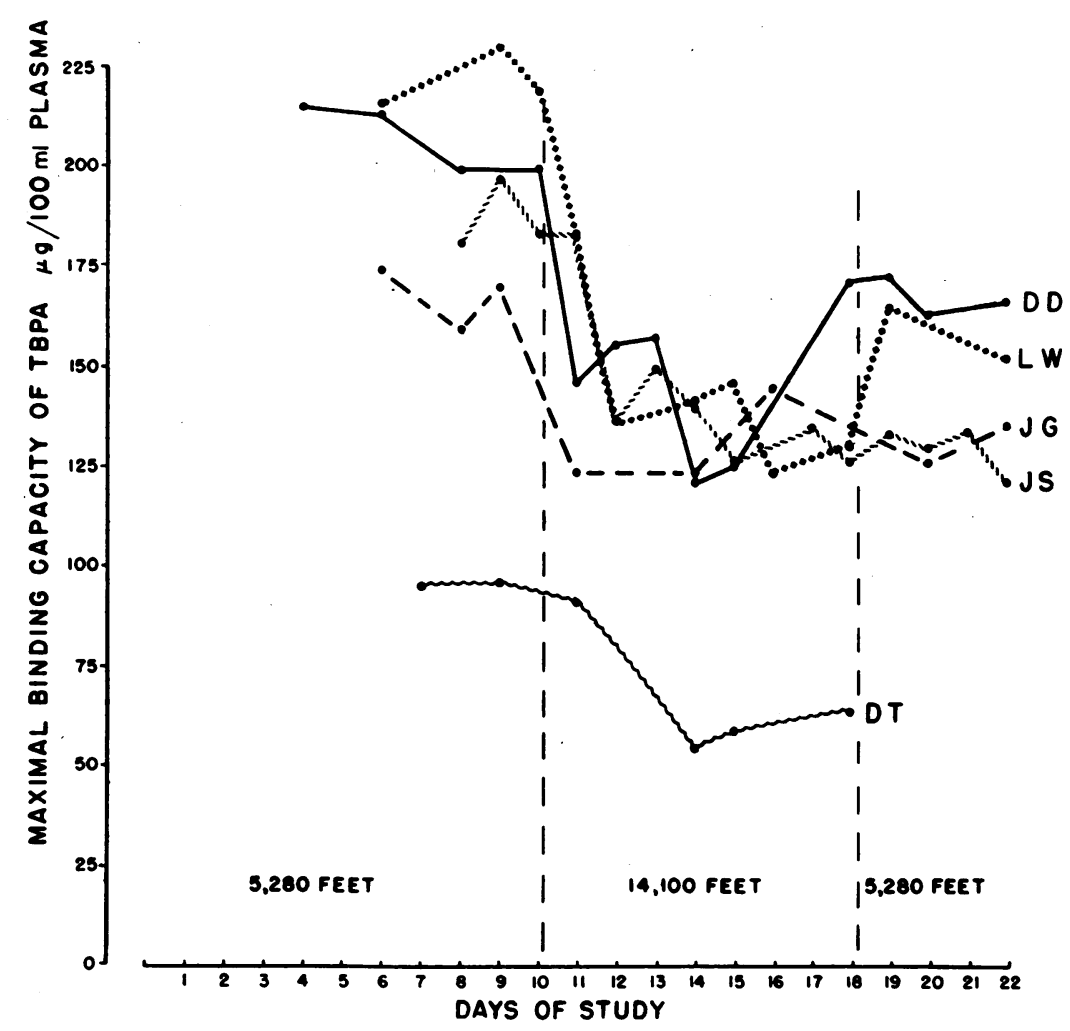

Fig. 5. MAXIMAL BINDING CAPACITY OF THYROXINE-BINDING PREALBUMIN

(TBPA) IN MAN AT HIGH ALTITUDE.

ance of $2.33 \mathrm{~g}$ per day (range 1.28 to $3.18 \mathrm{~g}$ per day). Nitrogen balance remained negative in the recovery period. Body weight, measured daily, was stable initially, but a progressive decrease was observed in all subjects at high altitude. The mean maximal weight loss was $2.14 \mathrm{~kg}$ (range 1.37 to $3.75 \mathrm{~kg}$ ) representing $3.01 \%$ of initial body weight. Weight lost at altitude was not regained during the 4-day postaltitude period.

Alterations in thyroxine-binding prealbumin concentration and various indexes of thyroid function. A marked decrease in the concentration of TBPA was observed in all subjects at 14,100 feet (Figure 5). Significant changes were noted on the first altitude day, but the maximal decrease (mean $62 \%$ of the control) did not occur until the fourth to sixth altitude days. D.D. and L.W. showed some return toward control values during the postaltitude period, but TBPA concentration remained significantly depressed in all subjects at the conclusion of the study. Although the control TBPA concentration was be- low the normal range in D.T., the changes due to altitude were similar to those in the other subjects. Plasma free thyroxine concentration was elevated in four of the subjects due to an increase in the plasma total thyroxine concentration as well as diminished thyroxine binding by plasma proteins. The changes were maximal during the last 2 days at altitude. Thyroxine degradation, measured by the turnover of ${ }^{125} \mathrm{I}$-labeled thyroxine, appeared to be increased during the first 3 days of altitude exposure.

\section{Discussion}

A moderate increase in albumin degradation, lasting 24 to 48 hours, occurred in all subjects during the first 3 days after acute exposure to high altitude. This change was accompanied by an increased plasma albumin concentration in all subjects except D.T. Since the electrophoretic distribution of the plasma proteins was unaltered, the data suggest that, like the previous study (1), the plasma proteins were concentrated as a re- 
sult of water loss from the IV compartment. The progressive decrease in plasma volume observed at high altitude here and by others (15-17) supports this interpretation. The small increases in plasma hemoglobin concentration and hematocrit (1 to $3 \%$ ) observed during the altitude period make it unlikely that increased red blood cell formation in this environment was primarily responsible for this change. The fact that plasma protein concentration is initially elevated infers that the rate of IV water loss must temporarily exceed the ability of the proteins to re-equilibrate with the EV compartment. Although this imbalance persisted for only several days in this study, elevated plasma protein concentrations were still noted 2 weeks after 8 subjects were taken to the same altitude from sea level (1). The degree of altitude "stress," therefore, appears to play some as yet undefined role in the magnitude of these changes.

Increased adrenocortical activity during the early phase of high altitude exposure has been reported (18-20) and might influence these data indirectly by increasing the renal clearance of nonprotein ${ }^{131} \mathrm{I}$ released from degraded protein (21), or directly by affecting protein synthesis or catabolism. Although it is frequently assumed that labeled iodide, monoiodotyrosine, and diiodotyrosine, which are the principal breakdown products of iodinated proteins, are excreted instantaneously, they are, in fact, distributed throughout the body in low concentration according to the rate of protein catabolism and the size of their individual pools (10). The lag in renal excretion of these degradation products after their release from the protein molecule has been estimated not to significantly affect urinary excretion data in the normal subject (22). The direct effects of excessive concentrations of the glucocorticoids on albumin metabolism have also been studied, either when these compounds were administered to man or animals $(23,24)$ or in Cushing's syndrome (25). There is general agreement among these studies that cortisol effects an increase in albumin degradation as well as an increase in synthesis, although the latter effect is smaller. The subjects' previous acclimatization to 5,280 feet altitude and almost complete lack of mountain sickness during acute high altitude exposure, however, make it extremely unlikely that increases in cor- tisol secretion sufficient to alter albumin metabolism directly or indirectly were present in this investigation.

Initially after altitude exposure, a decreased rate of fall of the EV activity curve $\left(Q_{E}\right)$ was accompanied by an increased rate of fall of the IV activity curve $\left(Q_{P}\right)$. Towards the end of the altitude period more marked changes in the opposite direction were observed. The concomitant rise in plasma albumin specific activity indicates that large amounts of high specific activity albumin entered the IV compartment from the EV albumin pool at that time. From this observation and the alterations in plasma volume noted above, it is concluded that marked intercompartmental shifts of fluid and metabolites occur during acute exposure to this environment. The function $k_{\text {in }}$ calculated from these curves was increased during the first 3 days at altitude but decreased markedly just before descent to the Denver laboratory. These data must be interpreted with caution because of the small group of subjects employed and the large intercompartmental shifts that were observed. Although the precise relative contributions of albumin synthesis and intercompartmental transfer to $k_{\text {in }}$ cannot be ascertained, it appears possible that albumin synthesis may be reduced towards the end of altitude exposure. Since the liver is the site of albumin synthesis (26), alterations in some hepatocellular functions involved in protein synthesis might occur in this environment. The studies of Klain (27), who recently observed decreased incorporation of injected ${ }^{14} \mathrm{C}$-labeled glutamic acid and alanine into liver protein of rats at 14,100 feet, would be in accord with this hypothesis. The metabolism of immunoglobulins that are not synthesized primarily by the liver is not affected by high altitude. Trapani has reported (28) that rabbits at high altitude $(12,000$ feet) demonstrate normal or increased antibody production when challenged with antigen. The rate of removal of immunoglobulins determined after passive transfer of antibodies to these animals was unchanged.

A negative nitrogen balance has previously been reported in animals $(29,30)$ and man (31) at high altitude. In the present study, nitrogen balance was most negative during the latter period of exposure. At that time the intake of calories and protein was reduced due to appetite impairment. 
The mean minimal protein intake, $0.90 \mathrm{~g}$ per $\mathrm{kg}$ per day, was not, however, sufficiently low to alter protein metabolism itself. Alterations in nitrogen balance were minimal during the first 2 days at altitude when albumin catabolism was greatly increased. The probability exists that amino acids released from degraded albumin at that time were reutilized for the synthesis of other plasma or tissue proteins required to meet the new metabolic demands of this hypoxic environment. Thus, conclusions based on the turnover of albumin may not be readily extrapolated to the state of protein metabolism in the entire organism.

The effects of thyroid hormone on albumin metabolism have been investigated in hypothyroid $(32,33)$ and euthyroid $(34,35)$ subjects. The results of these studies indicate that thyroid hormone produces an increase in albumin degradation together with an increase in synthesis. No reports are available concerning the relationship of thyroxine utilization and plasma free thyroxine concentration to the parameters of protein metabolism measured in this study. Early during altitude exposure increased degradation of thyroxine paralleled the increased rate of albumin synthesis and degradation. Plasma thyroxine concentrations were unchanged. During the last 5 days at 14,100 feet, however, plasma total and free thyroxine concentrations were elevated. Since free thyroxine presumably represents the hormone available to the tissues (36), and since thyroxine stimulates the incorporation of amino acids into rat liver protein (37), an increased rate of albumin synthesis was anticipated at this time. The opposite may have occurred. Although the fractional rate of albumin degradation remained moderately elevated, the rate of synthesis may have been decreased. The data would appear to show, therefore, possible interference with the stimulation of protein synthesis by thyroxine during acute exposure to this environment. Whether the interference is at the cellular level or related to changes in tissue blood flow or to other factors remains to be elucidated.

As in all studies of this nature, the quality of the tracer employed is of great importance in data interpretation. In the present investigation, the initial degradation rate was more than 4 to $5 \%$ of the retained activity per day during the first few days after injection and, in two subjects, the plasma curve, $Q_{\mathbf{P}}$, did not decline at a constant rate. According to the criteria of Berson and associates (10), these observations suggest that the preparation of albumin-131I employed was not entirely satisfactory. If this interpretation is correct, the values presented for the albumin degradation rate during the control period might be falsely elevated. Since the more rapidly degraded components in this preparation would be metabolized before the experimental period, the observations made at that time would still be valid.

The present study emphasizes the difficulties that arise in the analysis of turnover data in the nonsteady state. Other investigators have approached this problem by assuming the constancy of pool sizes (23) or the uniformity of specific activity throughout the body (34), or by using a second injection of labeled albumin to redetermine the size of the total body albumin pool (24). The assumptions implicit in these methods, justified in experimental situations where metabolic events change relatively slowly, would lead possibly to erroneous conclusions in the present study where pool size and plasma albumin specific activity change rapidly from day to day. The frequent measurement of the size of the IV pool as well as the use of the digital computer for the derivation of expressions to adequately describe complex data curves obviates these problems to some degree. However, it should be emphasized that accurate assessment of small transient changes in albumin metabolism in the nonsteady state cannot be achieved by any method currently available.

\section{Summary}

The metabolism of human serum albumin was studied by means of albumin-131 I in five young males at 5,280 feet and for 8 days at 14,100 feet altitude. The data were analyzed in a manner that made possible the daily estimation of the rate of albumin degradation and synthesis + net transfer from the extravascular to intravascular compartments.

Albumin degradation was increased markedly for 24 to 48 hours within the first 3 days at high altitude. A large shift of high specific activity albumin from the extravascular to intravascular compartments occurred towards the end of altitude exposure and was accompanied by a decrease in the rate of albumin synthesis + net transfer. 
A decrease in the intake of calories and protein (minimum $-0.90 \mathrm{~g}$ per $\mathrm{kg}$ per day) as well as a negative nitrogen balance was observed during the high altitude period.

The data are discussed in relation to changes in thyroid and adrenocortical function that have been observed in this environment.

\section{Acknowledgments}

The author is indebted to Lt. Col. J. E. Canham and to J. P. Hannon for their enthusiastic support; to the city of Colorado Springs and Helen Stuart, Inc., for providing utilities and logistical support on Pikes Peak; to W. F. Carle for his generous help; to the National Forestry Service, Dept. of Agriculture for allowing the use of Pikes Peak; to Lt. Col. W. A. Pacey for the procurement of the volunteers; to the staff of the Metabolic Division of this laboratory for their meticulous care in the preparation of the diets and collection of specimens; to D. L. Anderson, Programming Advisor, University of Colorado Computing Center, for his generous assistance in the solution of the data curves; to the Analytical Chemistry Division of this laboratory for performing the Kjeldahl nitrogen determinations and membrane electrophoresis; and to the subjects themselves for their enthusiastic cooperation during all phases of the study.

The expert technical assistance of W. J. Murray, SP-4, and H. C. Maddox, Jr., SP-5, is deeply appreciated.

\section{References}

1. Surks, M. I. Elevated PBI, free thyroxine and plasma protein concentration in man at high altitude. J. appl. Physiol. 1966, in press.

2. Oppenheimer, J. H., M. I. Surks, G. Bernstein, and J. C. Smith. Metabolism of iodine 131 labeled thyroxine-binding prealbumin in man. Science 1965, 149, 748.

3. Socolow, E. L., K. A. Woeber, R. H. Purdy, M. T. Holloway, and S. H. Ingbar. Preparation of $\mathrm{I}^{\mathrm{in}}$ labeled human serum prealbumin and its metabolism in normal and sick patients. J. clin. Invest. $1965,44,1600$.

4. Berson, S. A., and R. S. Yalow. Radiochemical and radiobiological alterations of $\mathrm{I}^{181}$-labeled proteins in solution. Ann. N. Y. Acad. Sci. 1957, 70, 56.

5. Lowry, O. H., N. J. Rosebrough, A. L. Farr, and R. J. Randall. Protein measurement with the Folin phenol reagent. J. biol. Chem. 1951, 193, 265.

6. Hiller, A., J. Plazin, and D. D. Van Slyke. A study of conditions for Kjeldahl determination of nitrogen in proteins. Description of methods with mercury as catalyst, and titrimetric and gasometric measurements of the ammonia formed. J. biol. Chem. 1948, 176, 1401.
7. Pileggi, V. J., N. D. Lee, O. J. Golub, and R. J. Henry. Determination of iodine compounds in serum. I. Serum thyroxine in the presence of some iodine contaminants. J. clin. Endocr. 1961, 21, 1272.

8. Oppenheimer, J. H., R. Squef, M. I. Surks, and H. Hauer. Binding of thyroxine by serum proteins evaluated by equilibrium dialysis and electrophoretic techniques. Alterations in nonthyroidal illness. J. clin. Invest. 1963, 42, 1769.

9. Pearson, J. D., N. Veall, and H. Vetter. A practical method for plasma albumin turnover studies. Strahlentherapie Sonderbande 1958, 38, 290.

10. Berson, S. A., R. S. Yalow, S. S. Schreiber, and J. Post. Tracer experiments with $I^{121}$ labeled human serum albumin: distribution and degradation studies. J. clin. Invest. 1953, 32, 746.

11. Campbell, R. M., D. P. Cuthbertson, C. M. Matthews, and A. S. McFarlane. Behaviour of ${ }^{14} \mathrm{C}$ - and ${ }^{181} \mathrm{I}$ labelled plasma proteins in the rat. Int. J. appl. Radiat. 1956-57, 1, 66.

12. Matthews, C. M. E. Effects of plasmapheresis on albumin pools in rabbits. J. clin. Invest. 1961, 40, 603.

13. Biomedical Computer Programs, W. J. Dixon, Ed. Los Angeles, University of California, 1964, p. 233.

14. Johnson, P. O. Statistical Methods in Research. New York, Prentice Hall, 1949.

15. Consolazio, C. F., L. O. Matoush, and R. A. Nelson. Energy requirements of men performing moderate physical activities at 3,475 meters. U. S. Army Medical Research and Nutrition Laboratory Report no. 290.

16. Pugh, L. G. C. E. Physiological and medical aspects of the Himalayan scientific and mountaineering expedition, 1960-61. Brit. med. J. 1962, 2, 621.

17. Hannon, J. P., and C. W. Harris. High altitude acclimatization of college women. Fed. Proc. 1966, 25, 399.

18. Moncloa, F., J. Donayre, L. A. Sobrevilla, and R. Guerra-García. Endocrine studies at high altitude. II. Adrenal cortical function in sea level natives exposed to high altitudes ( 4300 meters) for two weeks. J. clin. Endocr. 1965, 25, 1640.

19. Timiras, P. S., N. Pace, and C. A. Hwang. Plasma and urine 17-hydroxycorticosteroid and urine 17ketosteroid levels in man during acclimatization to high altitude (abstract). Fed. Proc. 1957, 16, 340.

20. MacKinnon, P. C. B., M. E. Monk-Jones, and K. Fotherby. Study of various indices of adrenocortical activity during 23 days at high altitude. J. Endocr. 1963, 26, 555.

21. Berson, S. A., and R. S. Yalow. The effect of cortisone on the iodine accumulating function of the thyroid gland in euthyroid subjects. J. clin. Endocr. 1952, 12, 407.

22. Gitlin, D., and C. A. Janeway. Some isotopic studies on the distribution and metabolism of plasma proteins in Advances in Biological and Medical 
Physics, C. A. Tobias and J. H. Lawrence, Eds. New York, Academic Press, 1960, vol. 7, p. 249.

23. Grossman, J., A. A. Yalow, and R. E. Weston. A1bumin degradation and synthesis as influenced by hydrocortisone, corticotropin and infection. $\mathrm{Me}-$ tabolism 1960, 9, 528.

24. Rothschild, M. A., S. S. Schreiber, M. Oratz, and H. L. McGee. The effects of adrenocortical hormones on albumin metabolism studied with albumin-Isis. J. clin. Invest. 1958, 37, 1229.

25. Sterling, $K$. The effect of Cushing's syndrome upon serum albumin metabolism. J. clin. Invest. 1960, 39, 1900.

26. Miller, L. L., C. G. Bly, M. L. Watson, and W. F. Bale. The dominant role of the liver in plasma protein synthesis. J. exp. Med. 1951, 94, 431.

27. Klain, G. J. Personal communication.

28. Trapani, I. L. Immunophysiological considerations of antibody formation at high altitude in The Physiological Effects of High Altitude, W. H. Weihe, Ed. New York, Pergamon, 1964, p. 167.

29. Brunquist, E. H., E. J. Schneller, and A. S. Loevenhart. The effects of anoxemia on nitrogen metabolism. J. biol. Chem. 1924-25, 62, 93.

30. Evans, G. The adrenal cortex and endogenous carbohydrate formation. Amer. J. Physiol. 1935-36, 114, 297.

31. Consolazio, C. F., L. O. Matoush, and R. A. Nelson.
Energy requirements of men performing moderate physical activities at 4,300 meters. U. S. Army Medical Research and Nutrition Laboratory Report no. 289.

32. Lewallen, C. G., J. E. Rall, and M. Berman. Studies of iodoalbumin metabolism. II. The effects of thyroid hormone. J. clin. Invest. 1959, 38, 88.

33. Schwartz, E. The effect of thyroid hormone upon the degradation rate and miscible pool of radioiodinated human serum albumin in myxedema. $\mathrm{J}$. Lab. clin. Med. 1955, 45, 340.

34. Iber, F. L., K. Nassau, I. C. Plough, F. M. Berger, W. H. Meroney, and K. Fremont-Smith. The use of radioiodinated albumin in metabolic studies. The effects of the level of dietary protein and L-triiodothyronine on the catabolism of radioiodinated human serum albumin. J. clin. Invest. 1958, 37, 1442.

35. Rothschild, M. A., A Bauman, R. S. Yalow, and S. A. Berson. The effect of large doses of desiccated thyroid on the distribution and metabolism of albumin- $\mathrm{I}^{181}$ in euthyroid subjects. $\mathrm{J}$. clin. Invest. 1957, 36, 422.

36. Robbins, J., and J. E. Rall. Proteins associated with the thyroid hormones. Physiol. Rev. 1960, 40, 415.

37. Sokoloff, L., and S. Kaufman. Thyroxine stimulation of amino acid incorporation into protein. J. biol. Chem. 1961, 236, 795. 